University of South Carolina

Scholar Commons

Summer 7-1-2003

\title{
Justice by Paperwork: A Day in the Life of a Court Scribe in Bourbon Mexico City
}

Michael C. Scardaville

University of South Carolina - Columbia, mscardaville@sc.edu

Follow this and additional works at: https://scholarcommons.sc.edu/hist_facpub

Part of the History Commons

Publication Info

Published in Journal of Social History, Volume 36, Issue 4, Summer 2003, pages 979-1007.

http://chnm.gmu.edu/jsh/

(C) 2003 by Carnegie Mellon University Press

This Article is brought to you by the History, Department of at Scholar Commons. It has been accepted for inclusion in Faculty Publications by an authorized administrator of Scholar Commons. For more information, please contact digres@mailbox.sc.edu. 


\title{
JUSTICE BY PAPERWORK: A DAY IN THE LIFE OF A COURT SCRIBE IN BOURBON MEXICO CITY
}

\author{
By Michael C. Scardaville
}

University of South Carolina

After recounting his seven years of loyal and unfailing service as a scribe (escribano) in Mexico City, Mariano Espinosa proceeded to express his concerns to the magistrates of the Sala del Crimen, the high criminal court of New Spain. In a 1795 petition for a remunerated appointment in the Sala, he complained about "the onerous duties of (his current) position, working throughout the day and night.... with an incessant and daily fatigue (and) ... a very limited income." Disappointed by the ministers' unwillingness to grant his request, Espinosa submitted a second petition three years later in which he explained the physical and financial burdens of his job in more graphic terms. After reminding the magistrates of the high court that he has been an escribano "without any salary save for the immense work, travails, inconveniences and miseries that the criminal justice system produces, which is well-known to the Ministers (of the court)," he then described his typical daily duties as escribano:

from before eight until after eleven in the morning, this subordinate official is present to assist his magistrate with the expected respect and decorum: subsequently working in the houses of the Lord Ministers, he continues dispatching the serious and minor criminal cases as well as the other important tasks until he leaves at one, two, or three o'clock in the afternoon. Without more than one or two hours of rest, he returns to the office of the Lord Minister to assist in continuing the responsibilities of his occupation until the evening prayer. Afterwards he assists the above Ministers or their ward police officials (alcaldes de Quartel) on their evening patrols until ten, eleven, or twelve o'clock, since it commonly happens that incidents of homicides, aggravated assaults, robberies, and other serious crimes, which one cannot avoid noticing, occur in these late hours. It happens, moreover, that more crimes are committed on holidays, because of the increase of public drunkenness, than on workdays so that the need to locate witnesses and undertake judicial investigations further deprives one of the short rest period that is left. $^{1}$

Shall we dismiss these comments as the kind of hyperbole that historians of colonial Mexico and Spanish America have come to expect in petitions to the government, or is there any substance to Espinosa's claims? And if indeed he did not exaggerate, then what do his quotidian tasks and workload tell us about the municipal criminal justice system, especially the nature of judicial proceedings, at a critical time of rapid urban growth, expanding poverty, and government and elite fears of social disorder and popular unrest in the capital of the Viceroyalty of New Spain? While I am not able to reconstruct Espinosa's particular work routine from the existing records, it is possible to assess his petitions, and ultimately the nature of criminal judicial procedure, by reconstructing a "typical" day in the life of an escribano who worked in the lower criminal courts of Mexico City in the decades before the outbreak of the tumultuous independence movement in 1810. 
What can we possibly learn about the local criminal justice system by examining the work of such a low-level official of the court? $?^{2}$ Following an escribano on his daily rounds, I would contend, ultimately provides a means to evaluate the prevailing scholarly view of criminal judicial administration in Bourbon Mexico and the nature of the late colonial state. Generations of historians, as well as nineteenth-century Liberal and Positivist critics, have asserted that the Bourbon authorities in Mexico City and throughout the colony maintained a criminal justice system that was corrupt, arbitrary, abusive, and unjust, and showed little respect for due process of law. According to this perspective, the absolutist Bourbon state embraced oppressive criminal legal practices as one of the principal means of controlling the popular groups, upholding public order, and ultimately sustaining the state's authority through coercion and fear. ${ }^{3}$

By continuing to embrace this one-dimensional view of the Bourbon state and its elite allies, a view which obscures the multiple ways in which the state was experienced and understood, most scholars of colonial law and judicial administration in Mexico City tenaciously cling to what historians of early modern Europe have shown to be a questionable model of an absolutist state. In the last fifteen years, the literature on European state formation has offered a more complex and nuanced understanding of royal absolutism that disputes the conventional notion that monarchs of the ancien régime exercised absolute and, in some instances, despotic power. These studies illustrate that the concept and historiography of 'absolutism' were largely products of both royal rhetoric and the diatribes of nineteenth-century Liberals who denounced the earlier regimes as part of their ideological struggles against the post-Napoleonic conservative restoration monarchies. When stripped of its "mythology," the early modern state that emerges from this recent literature is one that generally is not despotic, arbitrary, or autocratic, even in the period of "Enlightened Despotism." In spite of the rhetoric and imagery of 'absolutism,' institutional prerogatives, customs, and law, even criminal law, constrained state power, and the monarch was expected to and largely did respect the rights of his subjects. This revisionist understanding of the ancien régime, which is sensitive to the pre-modern balance between absolute and limited authority, can prove helpful in rethinking the prevailing notion of criminal judicial administration in Mexico City in particular and the late colonial state in general. ${ }^{4}$

Another shortcoming of the dominant view of judicial and other state institutions in colonial Mexico City is that it primarily emphasizes government objectives and policies, and the responses to these initiatives, while devoting less attention to the institutional processes and means by which such intended outcomes were generated, an approach that thereby ignores the crucial aspect of how institutions work. ${ }^{5}$ The inner and intimate workings of public institutions provide insight into issues of state power and legitimacy as well as popular perceptions and responses. How institutions operate, not simply what they try to accomplish, also shapes how they are viewed by individuals and groups of all social classes. While historians know much about the structure of the expanded municipal criminal justice system in Mexico City, which by the end of the eighteenth century processed over 10,000 cases annually, little has been written about how it functioned on a daily basis. This essay will emphasize that it is not simply in the final court decisions, but also in the everyday and mundane 
operations of the courts, such as in the criminal procedural forms and methods practiced by judicial officials, that working-class people in Mexico City formed opinions about the fairness of the law, which in turn helped shape notions about their relationship with the multi-faceted colonial state. ${ }^{6}$

\section{$* * * * *$}

In the late eighteenth and early nineteenth centuries, Mexico City, the largest city in the Western Hemisphere at that time, experienced what Silvia Arrom refers to as its "first 'urban crisis'" as mounting economic difficulties confronted most residents of the capital. ${ }^{7}$ Life for the popular classes became more arduous and less secure in the closing decades of colonial era. The working poor, a diverse group of Spanish, Indian, and casta (mixed ethnic background) artisans and day laborers who comprised roughly three-quarters of Mexico City's $125,000-160,000$ residents, suffered from a severe labor surplus, inflation, wage stagnation, periodic subsistence crises, and an overall decline in living standards, developments which were fueled by high annual urban growth rates and which resulted in, by all accounts, increased levels of crime. The viceregal authorities responded to what they perceived as an unstable and dangerous situation by expanding the police and local court system in the early 1780 s and by relying on military patrols to maintain "public tranquility." 8 In language that expressed their economic and cultural distance from members of urban popular groups, government officials and the city's wealthier residents publicly described the increasingly impoverished working poor of Mexico City in a contemptuous and condescending, yet always anxious manner. ${ }^{9}$

To what extent did such fears shape the administration of criminal justice in the rapidly-growing metropolis? Did they ultimately lead to the arbitrary and abusive legal behavior that historians have claimed was the norm in the late colonial period? One profitable way to address these issues and assess the detailed operation of the local criminal justice system is to examine the duties of an escribano like Mariano Espinosa. ${ }^{10}$ The workhorses of the judiciary in Mexico City, as a close reading of criminal records will illustrate, were those escribanos who assisted one of the principal magistrates (jueces mayores) of the eight first instance tribunals or one or more of the thirty-two alcaldes de barrio or ward police officials. Spanish law dating back to the thirteenth-century Siete Partidas required scribes to be involved in every step of the judicial process, from arrest through sentencing, since all actions and activities had to be witnessed and recorded by the escribano in order to have legal validity. ${ }^{11}$ The magistrate and the scribe, both of whom were charged with ensuring that all cases were handled in accordance with the law and that legal guarantees were fulfilled, acted as the primary figures in the criminal judicial process. While the judge initiated the criminal proceedings, supervised the subsequent investigation, and issued major legal judgements, he typically delegated the investigation to his escribano, who in turn gathered the evidence necessary to assess the criminal charge..$^{12}$ In the Ibero-American judicial process, the escribano, as the eyes, ears, and feet of the court, was the most active and involved judicial official in criminal proceedings. ${ }^{13}$ Not merely a court reporter, he served as the principal 
investigator for the judge as well as the judicial officer who implemented the magistrate's decisions. In making certain that standard legal procedural norms were followed, the escribano ultimately played a significant role in determining the effectiveness and integrity of the criminal judicial system. ${ }^{14}$ In recognition of their crucial role, Charles III noted in 1788 that "the fair administration of justice ... (and) also the peace and tranquility of the communities ... depend in great part ... on the dedication and impartiality of the Scribes." 15 The escribano, though often absent in historians' narratives, was both the representative and embodiment of the legal culture in New Spain, or at least in Mexico City, where almost two-thirds of royal escribanos in the colony resided. ${ }^{16}$

The scribes' central role in legal cases required expertise in proper juridical forms and processes. How they acquired such knowledge depended on whether they were appointed as royal or as deputy scribes. Before receiving the title "escribano real," royal scribes, most of whom were creoles (locally-born Spaniards), undertook a four-year apprenticeship, studied published and manuscript legal handbooks and formularies, participated in workshops offered by Real Colegio de Escribanos after its establishment in 1792, and passed an examination administered by the Audiencia, the highest colonial court in New Spain. ${ }^{17}$ As a result of their personal background, education, and accreditation, escribanos reales were considered to be legal professionals, not mere clerks (i.e. escribientes).$^{18}$

Though scribes were central to the legal process, these judicial officials were in short supply in Mexico City and in the colony of New Spain as a whole at the end of the colonial period. ${ }^{19}$ There simply were not enough royal scribes to fill the forty positions prescribed by the expanded local criminal justice system in Mexico City. ${ }^{20}$ The solution to this shortfall was twofold. In an explicit recognition of this problem, viceregal authorities sanctioned in 1782 , originally as an interim measure, the appointment of escribanos habilitados, so-called deputy scribes who did not have to undergo the formal training and certification process required of escribanos reales. Dozens of these deputized officials, who, like Mariano Espinosa, were overwhelmingly creole in background, were deployed soon after the expanded judicial system became operational. ${ }^{21}$ Since this solution still did not produce enough scribes to fully staff the courts and assist the police, the viceroys appointed escribanos, both royal and deputy, to work in more than one minor district. 22 Some scribes served not only the magistrate of one of the cuarteles mayores, but also the four alcaldes de barrio who served in the precincts of that district. ${ }^{23}$

As a result of the pivotal role that escribanos played in the Ibero-American legal system, their presence in the expanded criminal justice system was mandatory, even if the viceregal authorities relied on deputy scribes to ensure compliance with legal norms and expectations. ${ }^{24}$ Although personal integrity and intellectual capability were the only specified qualifications necessary to serve as escribanos habilitados, the men named to these positions tended to have some legal experience prior to their appointment and had ready access to the same legal handbooks and formularies that helped train the royal scribes. ${ }^{25}$ Further, the escribanos habilitados, like the escribanos reales, generally served for many years, thereby acquiring substantial professional experience over time. ${ }^{26}$ In spite of occasional protests from the Rector of the Real Colegio de Escribanos over the continued use of the deputy scribes, the local magistrates, including those jurists 
who served as judges on the Sala del Crimen, praised the quality of their work. As cogent testimony to their more than acceptable performance, one of these high court magistrates, Manuel del Campo y Rivas, informed the viceroy in 1809 that he believed Mariano Urueña, the deputy scribe who assisted him and the four alcaldes de barrio in his district, had been trained at the Real Colegio de Escribanos and had passed the exam supervised by the Audiencia. ${ }^{27}$

Because of their experience and background in procedural law as well as their centrality in criminal proceedings, escribanos acted as legal advisors to the three municipal lay magistrates and the thirty-two alcaldes de barrio, judicial personnel who had no prior legal training. ${ }^{28}$ On a daily and recurring basis, the escribanos were a font of reliable knowledge about proper legal procedures from arrest to final sentencing, information that was particularly critical given the vast, complex, and sometimes contradictory nature of Spanish colonial law. ${ }^{29}$ Their advisory function was especially valuable considering the high rate of turnover in law enforcement and judicial positions and the demanding administrative duties of all the magistrates and ward police. ${ }^{30}$ Scribes provided for legal continuity in the courts of the municipal judges and in the neighborhood districts of the alcaldes de barrio. ${ }^{31}$ They ensured that in the daily administration of justice, lay magistrates and other judicial figures correctly followed procedural forms at each step in the criminal case. Particularly at the lower levels of the municipal criminal justice system, the escribano's knowledge of the legal process was essential for a smooth-running and legally-constituted judicial system. ${ }^{32}$

Given the importance of historicizing and contextualizing the daily operation of the criminal justice system, that is, to understand notions of law in a particular place and time, it is imperative to discuss the work routine of the court scribes and assess the administration of criminal justice on the basis of the extensive case file evidence, not, as has often been the case, on the second-hand comments of late colonial observers. Consequently, the following account of the judicial system and its officials is grounded largely on an analysis of almost 7,400 criminal cases processed in the lower courts of the viceregal capital between the early 1780 s and 1810.33

The average daily caseload for each scribe ranged from at least one to as many as ten, or twelve, or in some instances, fifteen. ${ }^{34}$ The number of criminal cases varied as a result of several factors. The viceroy could appoint escribanos to assist from one to as many as five judicial officials. ${ }^{35}$ The caseload also depended on the level of criminal activity and the resulting police work as well as the number of criminal charges filed by residents of the city. Weekends and religious holidays placed greater demands on all local judicial officials, particularly because of an extraordinary increase in the incidence of drink-related offenses. Finally, the workload of the escribanos related to the manner in which the magistrates handled the criminal cases. Depending on the gravity of the offense, the eight lower courts of Mexico City adjudicated criminal cases through either a juicio sumario or a juicio ordinario. ${ }^{36}$ More than nine of every ten criminal cases were processed as juicios sumarios, that is, summary or abbreviated proceedings for minor offenses in which the magistrates issued a sentence after preliminary testimony had been given and, if necessary, additional fact-finding investigations had been conducted. ${ }^{37}$ The more serious offenses, which necessitated more extensive judicial activities, became the juicios ordinarios, time-consuming cases 
that involved a more prolonged investigative phase before the magistrate issued a final sentence. ${ }^{38}$ With these variables in mind, we should remember that the many cases comprising the escribano's daily work routine fell into different stages of the criminal judicial process, from initial processing to judicial investigation, and ultimately to final sentencing.

What becomes notable upon reading many juicios is the routine, almost formulaic nature of criminal proceedings. While the predictability of legal procedure is observed again and again in the summary and more formal cases, I suggest that we do not ascertain the intimate workings of the criminal justice system, or its underlying principles, until we examine how it functioned in the course of a "typical" day. A description of one or several cases does not illustrate the daily workload and the professional commitment of an escribano. A better sense of judicial administration emerges when individual cases are placed within the larger context of an entire workday. ${ }^{39}$

The following composite picture of a representative day in the life of a scribe in Bourbon Mexico City will focus on his standard work practices, not on the anomalies that historians and penal critics have tended to portray as the juridical norm..$^{40}$ The day for an escribano customarily began between 7:00-8:00 in the morning in one of the local jails where he reviewed the Libro de entradas (Book of Admissions) for prisoners who had been arrested on the previous day by order of his magistrate or by his alcalde de barrio. ${ }^{41}$ After he recorded the particulars for each prisoner, such as the name, other biographical information, the arresting officer, and the nature of the offense, he proceeded, as was required by law, to take brief statements from each of the accused in the jail's sala de declaraciones (statement room) in order to document the reasons for their imprisonment and the circumstances behind the criminal charges. ${ }^{42}$ The escribano then returned to his office where he noted this information in abbreviated form in an arrest inventory he maintained, the Libro de reos, and prepared in writing a brief account (certificacion) of each of the new cases for the magistrate. Armed with the inventory and the certificaciones, as well as any of the files of the juicios ordinarios that were in need of court review, he then headed off to the office or home of the judge to personally deliver and, if necessary, explain this latest batch of judicial records. ${ }^{43}$

The judge began this meeting with his escribano by reviewing the new cases. If the offense was minor and the preliminary testimonies substantiated or refuted the charges, the magistrate, depending on the nature of the offense and the evidence, either pronounced the sentence or authorized additional legal procedures such as the submission of a medical report on the victim (fé de heridas), the preparation of a character investigation (averiguación de vida y costumbres), or the recording of testimony from the aggrieved party, eyewitnesses, and/or police officials. If preliminary evidence underscored the gravity of the offense or, in cases of aggravated assault, if the victim's life were in danger, the magistrate authorized the commencement of a more formal juicio ordinario, an injunction that typically outlined the nature of the subsequent investigation required of the scribe. For the juicios sumarios, the escribano dutifully recorded the judge's decrees (autos) in the arrest inventory. For the more formal juicios ordinarios, the scribe opened a new criminal file by transcribing the order dictated by the judge (auto cabeza del proceso) that initiated the sumaria, the first or probatory phase of the case. At 
this point, the magistrate turned his attention to the outstanding criminal files, reading the most current testimonies and the results of other judicial actions before issuing a sentence or ordering the escribano to undertake more inquiries or perform some other appropriate court action. After recording this batch of decrees in the files, the scribe gathered his documents and returned to his office to plan and coordinate his court-ordered responsibilities for the remainder of the day.

The case evidence suggests that the next portion of the day began with our escribano returning to the jail to notify the prisoners and the jailer, in writing and orally, of the judge's sentences, pronouncements that had to be signed or certified by all parties in front of the scribe. ${ }^{44}$ Upon leaving the jail, the escribano most likely turned his attention to the latest round of testimonies required by the judge. Taking statements generally consumed considerable time, especially since there was no one central location where these declarations were recorded. While he could take additional testimony from a prisoner before leaving the jail or find an assault victim in one of the hospitals, our escribano was forced to scurry all over the sprawling city to track down and take statements from eyewitnesses and police officials. Unquestionably, most demanding of his time were cases involving multiple prisoners and/or many witnesses.

Other standard judicial procedures performed by the scribe on any given day might include: recording and collecting medical reports from royal physicians; delivering criminal files to the asesor letrado or the magistrate of another criminal jurisdiction in the city; informing all parties involved in a case of the court's major rulings; arranging and conducting a careo (a face-to-face encounter between the accused and other parties and witnesses) in order to reconcile conflicting testimony; and implementing the provisions of the judge's sentence, such as sending a young boy to a workshop to learn a trade or making necessary arrangements for placing a woman in a depósito or casa de honra (forms of supervisory custody).

The escribano also had to find time during the day to manage his judicial books and files. He had to maintain and update all criminal records, such as the Libro de reos, the outstanding juicios ordinarios as well as a series of ledgers (Libros de conocimientos) of these materials, ${ }^{45}$ and the Sala del Crimen required him to prepare bi-weekly status reports of the formal criminal cases for which he was responsible. In addition, he attended to the many details of managing the individual case files, such as retrieving and filing any relevant materials, archiving completed files, and appending documents submitted by physicians, family members, and the prisoner. These daily routines could always be disrupted at any time if a crime were reported to his alcalde de barrio or juez mayor since, as stipulated by law, any arrest made after an accusation had been filed had to be properly recorded in the presence of an escribano. ${ }^{46}$ Such disruptions were a common occurrence since members of the popular classes of Mexico City filed thousands of such criminal complaints annually. ${ }^{47}$

The early evening hours brought little respite from the day's activities. A number of tasks required attention, such as implementing unfinished judicial orders, updating and delivering criminal files, and recording testimonies from witnesses who had not been located earlier that day. Finally, the escribano accompanied his judge or alcalde de barrio on the evening neighborhood patrols (rondas), where in 
the course of recording any arrests and other judicial actions they occasionally were exposed to life-threatening situations. ${ }^{48}$ These rondas generally began at 8:00 PM and sometimes were conducted on the hour until midnight or 1:00 AM.

While the above narrative describes a representative day for our archetypal escribano, we must remember that he was expected to perform these responsibilities for 14 to 18 hours daily, seven days a week, 365 days a year, with an increased workload on weekends and holidays. ${ }^{49}$ Moreover, in addition to this daily routine, he also discharged additional judicial responsibilities as the need arose. In 1787, for instance, the Sala del Crimen required all escribanos with active cases to participate in the weekly Saturday morning inspections of the city and royal jails. ${ }^{50}$ In addition, the magistrate or alcalde de barrio at times mandated special judicial actions of their scribes such as furnishing drawings of weapons and other evidence, summarizing complex and lengthy files, and accompanying a police official to examine a corpse in the middle of the night. ${ }^{51}$ Particularly time-consuming were the procedural actions required during any of the periodic levas de vagos (forced levies of alleged vagrants) or in implementing the occasional royal pardon. ${ }^{52}$

In addition to his regular and intermittent judicial responsibilities, the escribano also had to fulfill exacting administrative obligations, especially those relating to municipal administration, or Policía, which spawned reams of paperwork. In a governmental system that did not separate administrative and judicial functions, the magistrates and their alcaldes de barrio, in addition to their criminal law duties, were responsible for enforcing a myriad of edicts that attempted to regulate garbage collection, street paving and lighting, liquor violations, building codes, and animal control. ${ }^{53}$ The escribanos of these officials recorded and delivered the innumerable reports, some of them submitted weekly, that touched on local administrative matters. ${ }^{54}$

Finally, on top of their criminal and administrative charges, some of the scribes also possessed varying degrees of responsibilities in the preparation of civil lawsuits and notary records. Unlike the escribanos de cámara, the institutionallybased scribes who assisted the ministers of the Sala del Crimen, the escribanos of the municipal lay magistrates and the alcaldes de barrio maintained their own offices which, depending on their level of involvement in litigation and notary records, might be staffed with clerks and perhaps an apprentice. ${ }^{55}$

Even though the escribanos performed a remarkable amount of work on a recurring basis, we should not conclude as a matter of course that their seemingly excessive duties compromised the speed or quality of the criminal judicial process. Not seen in this daily snapshot is the expeditious nature of court activities. In the juicios sumarios, three of four people arrested were sentenced on the following day, with 90 percent of all the accused receiving their final court decisions within three days after incarceration. Even in the more procedurally involved juicios ordinarios, the average length of time from arrest to sentence was slightly less than two months. ${ }^{56}$ Moreover, the case evidence strongly suggests that the extensive responsibilities of the escribanos and the expeditious nature of judicial process did not generally undermine their effort to "get at the facts" of the case. Time and time again, as seen in thousands of cases, the scribes recorded the testimonies the judges ordered and, on many occasions, decided on their 
own if additional statements or other judicial procedures, such as a careo, were necessary to uncover and reconcile relevant information about the case. ${ }^{57}$

\section{$* * * * *$}

What might we learn about the criminal justice system in late Bourbon Mexico City from this intimate study of one of its judicial officials? What is striking at first glance is that the colonial legal system adhered to centuries-old standards of Spanish judicial procedure, in spite of the heavy caseload that fell on the shoulders of the understaffed courts and its overworked escribanos and in spite of publicly-expressed elite and government fears regarding the behavior of urban popular groups. Central to criminal proceedings, even in the overextended lower courts of rapidly-growing Mexico City, was the requirement that the accused must be allowed to defend themselves and that the magistrates must substantiate the charges before any punitive sentence could be imposed. Charles IV reiterated this fundamental juridical principle in a 1796 royal decree outlining proper criminal judicial procedure for cases involving resisting arrest: "I hereby declare and order that the Courts, using those judicial proofs that are established by the Law, henceforth shall not issue the sentences ... without beforehand legally proving the crime and (the guilt of) the criminals.... (I also order) that under no circumstances shall the testimony of the prisoner or the prisoners not be taken and their exceptions and defenses not be heard since it is through such measures that the Courts can proceed in their cases and render their decisions with careful and prudent deliberation, without the danger of oppressing the innocent, which is one of the commendable objectives in the administration of justice." 58 (Italics mine)

While Spanish colonial criminal law, like all penal codes, was designed to protect and bolster existing power relations and social inequalities, it also provided for certain procedural safeguards for all subjects involved in criminal proceedings. ${ }^{59}$ As seen in thousands of summary and formal criminal cases, judicial procedure, in its various forms, was customarily followed in the lower courts of Mexico City, despite the burgeoning caseload, staffing concerns, and growing fear of crime and other forms of social disorder.

Legal safeguards were repeatedly honored in the daily administration of criminal justice in late colonial Mexico City because of a shared understanding that state authority was based, in part, on the functioning of public institutions in ways that had become culturally expected by all social groups. The expectations of "justicia," which were frequently articulated in testimonies and criminal accusations of working-class people in Mexico City, were based on a widely-held notion of fairness, that is, the belief that the king and his agents would adhere to basic legal guarantees in a timely manner, and, as a result, would not treat his subjects in arbitrary, abusive, and unpredictable ways. ${ }^{60}$ The extent to which the criminal justice system routinely performed in culturally familiar ways influenced how popular groups assessed the fairness and hence the legitimacy of judicial institutions. ${ }^{61}$ The daily operation of the criminal justice system, as embodied in part in the procedural work of the escribano who regularly upheld legal and cultural norms, shaped popular notions of the state and thereby became one of the means through which public authority was sustained in late Bourbon Mexico City. ${ }^{62}$ 
While the everyday practices of the court, as partially seen in the work routine of the scribe, tempered arbitrary justice and largely met popular expectations, there was, nonetheless, room for possible abuses and problems. Let me briefly address the extent to which corruption and inefficiency might have undermined the operation and hence credibility of criminal judicial institutions in Mexico City. The traditional fee-based system of remuneration for scribes offered the potential for extortion, but I contend that this method of compensation for judicial services did not create major problems for most working-class people who came into contact with the criminal legal system. Careful reading of the case evidence, against the backdrop of established and expected procedural norms, does not suggest that charging excessive and unnecessary fees was a common problem in the criminal proceedings of the city's lower courts. ${ }^{63}$ If financial considerations solely or largely motivated the daily behavior of scribes and other judicial officials, one would assume that, because of the additional fee-based procedural actions required in the formal criminal cases, more juicios ordinarios, and fewer summary cases, would have been authorized, but, as seen repeatedly in the case files, the decision to handle a case as a sumario or an ordinario was based on the gravity of the offense, not on the potential for generating fees for the scribe and other court officials. Another possible financial abuse was that in the juicios ordinarios, the judge, as advised by his escribano, could have mandated more fee-based judicial actions. What typically occurred in the more formal cases, however, was that the magistrate, if fully convinced of the culpability of the accused, terminated the case upon completion of the investigative phase (sumaria), thereby avoiding the redundant and often dispensable plenario phase, a more time-consuming and expensive part of the trial in which the parties offered a complex series of judicial proofs. ${ }^{64}$

There is little evidence to suggest that the scribes unnecessarily prolonged their judicial activities in spite of a fee structure that in principle would have financially rewarded such behavior. For instance, for conducting a careo, the arancel (sanctioned fee list) authorized the escribanos to collect one peso from each prisoner who participated in this judicial confrontation. ${ }^{65}$ Given the fact that the magistrate typically gave his scribe discretion to call for this procedural action, the escribano could have easily abused his authority by authorizing numerous careos, but the only time they appear in the records was when the scribe wished to resolve major discrepancies in the testimonies before the judge issued the final sentence. In all, the magistrates and escribanos typically did not call for unnecessary judicial procedures to increase the total amount of fees the scribe could collect. These judicial officials typically undertook the necessary, but minimal steps in their handling of the criminal cases. Ultimately, we should bear in mind that the judges, in accordance with royal legislation, often waived the payment of scribe fees for indigents, a decision that not only lessened the financial burdens of criminal justice on the poor, but also provided an incentive to expedite the criminal proceedings. ${ }^{66}$

The potential for monetary abuses was far greater in the civil lawsuits processed in Mexico City. Not only did the parties embroiled in litigation generally have more financial resources than those who became involved in the criminal judiciary, the evidence also suggests that escribanos reales and lawyers in civil 
cases prolonged proceedings on many occasions if it were in the interests of their clients, and themselves, to delay. ${ }^{67}$ While some criminal cases surely were affected by financial abuses, they simply did not offer the potential for monetary gain that the civil cases did. ${ }^{68}$ The more lucrative civil law practices of the scribes tended to make the daily operation of the criminal judicial system more honest. ${ }^{69}$

Chronic delays in the handling of criminal cases might have compromised the expectations of justice, but very few cases were excessively drawn out. Once again, the case file evidence provides insight into the relatively few protracted proceedings. In general, procedural delays were not the result of negligence and mismanagement on the part of court personnel, although in some instances an overworked and understaffed bureaucracy misplaced criminal files, which did postpone the implementation of judicial actions and prolong incarceration. ${ }^{70}$ Delays were much more likely a result of other factors. A magistrate could have ordered additional procedural steps if he were not convinced he had all the information necessary to issue an appropriate sentence; or the case involved another criminal jurisdiction in the city, which consequently necessitated additional judicial actions; or the aggrieved parties dragged their feet in order to keep the accused from leaving jail; or the court was waiting for an assault victim to recover from injuries before passing sentence. ${ }^{71}$

This understanding and portrayal of the criminal justice system of late colonial Mexico City does not seek to deny that law can be coercive and that power is embedded in court procedures. ${ }^{72}$ Criminal law can and does impose rules and punishments, and its power also can be expressed in the manner in which the judicial process shapes experiences and meanings. The key is in how that power is expressed, and as is seen through the daily activities of the escribano, the courts did not withhold legal guarantees and ultimately issue arbitrary and unduly harsh sentences. ${ }^{73}$

But why was this so, particularly at a time of rapid urban change, increasing crime, and resulting elite and government concerns? Why did the escribanos of late Bourbon Mexico City continue, day-in and day-out, to take testimonies and resolve discrepancies, in even the most minor of offenses, and why did the local magistrates continue to base their sentences on the evidence gathered in these judicial investigations? What ensured routine adherence to judicial procedure, and thereby minimized the possibility of politicizing criminal justice, was the continued and systematic application of the medieval juridical doctrine of arbitrio judicial..$^{74}$ This concept, best understood as judicial will or discretion, simply meant that the magistrate could modify the legally-prescribed sentence in order to render a judgment that sought equidad (equity) and maximized the common good. As noted in the legal codes, a just and proper sentence had to be based on evidence, the circumstances of the crime, and the background of the accused, information the escribano collected in the probatory phase of the case. Before issuing sentence, the judge assessed such factors as criminal intent, motive, severity and place of crime, as well as the economic and ethnic status of the accused. The ultimate objective, as stipulated by law and practiced in the courts of colonial Mexico City, was that a magistrate would pronounce a sentence that was proportionate to the crime and therefore tailored to the particular case, 
even if it meant that his decree modified the penalties specified in the laws. This judicial flexibility, as evidenced by the routine evoking of arbitrio judicial, depended on the standard and uniform application of judicial procedure.

Eighteenth- and nineteenth-century penal reformers and theorists as well as many historians of crime and Ibero-American law have mistakenly regarded arbitrio judicial as another example of an abusive and capricious absolutist state. ${ }^{75}$ The potential for abuses clearly existed, since the magistrates, in accordance with their personal preferences and impulses, could have decided to issue sentences without undertaking the necessary probatory measures. However, examination of thousands of criminal records from late colonial Mexico City unearths little evidence of such legal misconduct. Judicial process was followed, sentences were moderate and proportionate to the offense, and the judges as a matter of course released the accused if there was insufficient evidence. Understood in the context of Ibero-American legal traditions, the concept of arbitrio judicial represented not so much a corruption of justice, as is typically portrayed in the literature, but rather an opportunity to shape the law to reflect, or at least strike some balance between, popular and elite expectations. ${ }^{76}$

The practice of arbitrio judicial had political repercussions that have not been addressed in the historical literature, but are relevant to the issues raised in this essay. The principle of judicial discretion, with origins in medieval Natural Law, enabled both the superior and the inferior magistrates in Mexico City to maintain some distance from the wishes and intent of the colonial Bourbon state. While judges and other judicial officials were, indeed, representatives of the government, they often acted independently of the state. ${ }^{77}$ The legally-constituted authority to modify existing laws to fit the circumstances of the crime and to issue sentences that reflected what they believed were just and proper afforded a degree of autonomy to magistrates. Although such autonomy cushioned the full impact of state power, the Bourbons, even when they repeatedly called for adherence to sentences specified in the laws, ultimately did not tamper with the relative independence of the judges. Moreover, the growing fears of urban disorder, combined with an overextended and understaffed local court system, could have enticed the magistrates to neglect extensive judicial investigations and simply issue arbitrary and harsh sentences, but, as we have seen, they did not. This judicial and political behavior, both in the criminal courts as well as in the offices of the Bourbon policy makers, reflects the respect for and adherence to a deeply-entrenched legal culture in late colonial Mexico City.

To fully comprehend the nature of the criminal justice system in Mexico City is to understand that the judicial power of the colonial state and its agents was not to be found in the trappings, rituals, and royal regalia of the court. ${ }^{8}$ As seen in the daily activities of an escribano, there were no courtroom trials in the IberoAmerican legal tradition, a judicial style that, unlike its eighteenth-century English counterpart, was not publicly magisterial. The so-called criminal "trial" in the Spanish colonial legal system was more of a dispersed, bureaucratic investigation, which culminated in a final judicial ruling. There were no formal court hearings in late colonial Mexico City, but the escribano recorded testimony and performed other judicial actions, ultimately delivering a complete investigative report or dossier to the magistrate to read before he issued the final sentence. ${ }^{79}$ The judge rarely saw the accused, not even to pronounce the sentence and issue 
the usual admonition, but he did meet with his escribano every day to ensure that the proper and expected legal actions were being undertaken..$^{80}$

It was justice by paperwork, with the escribano, as an intermediary between state and society, involved in every step. ${ }^{81}$ In fulfilling his procedural responsibilities, the scribe functioned as one of the many lesser royal officials through whom Spanish power was expressed and its authority conditionally assured ${ }^{82}$ By generally adhering to cultural expectations of the law, as expressed in routine and quotidian court procedures and outcomes, the principal court officials, the magistrate and the escribano, helped to foster and sustain legitimacy for judicial institutions in late colonial Mexico City. ${ }^{83}$

\section{$* * * * *$}

Let us now return to Mariano Espinosa's petitions and briefly re-examine them within a broader understanding of the customary responsibilities of the escribanos. The evidence suggests that Espinosa was not exaggerating his claims and that he was, indeed, an overworked official in an understaffed judiciary. The meager income he earned for the demanding and sometimes dangerous criminal judicial work motivated Espinosa to seek salaried employment in the viceregal bureaucracy, which he finally secured by 1806 when we find him in a low-level legal position in the Sala del Crimen. ${ }^{84}$

As seen in the criminal procedures performed day after day by Espinosa and other escribanos, late colonial royal and municipal officials, in an era of expanding urban poverty, growing fear of crime and a concomitant enhancement of public security measures, did not exercise judicial power in an arbitrary or capricious manner. ${ }^{85}$ Such legal behavior fostered, I would suggest, a widespread acceptance of the legitimacy of criminal judicial institutions in Mexico City, an acceptance based in part on the court's adherence to expectations of procedural fairness and as evidenced by the thousands of poor people from diverse backgrounds who voluntarily went to the courts each year as a means of seeking "justicia," righting wrongs, and pursuing various strategic objectives. ${ }^{86}$ This is not to say that force was absent in the criminal justice system, but coercion is best understood as part of a wider array of other, less harsh methods of securing social cooperation. Contrary to what others have claimed about the colonial system of criminal justice, the Bourbons did not rule in Mexico City largely through fear. ${ }^{87}$

While this essay does not address other regions of New Spain or earlier periods in Mexico City, the procedural case evidence suggests that fundamental juridical elements of the medieval and early modern Hapsburg states endured in Mexico City toward the end of Bourbon rule. ${ }^{88}$ Late colonial royal policy makers unquestionably attempted to rationalize and centralize government institutions, but they did not challenge traditional, pre-Enlightenment juridical principles, principles that, as the literature on European state formation also has demonstrated, checked unbridled royal power and worked to limit the authority of the "absolutist" Bourbon state.

By continuing to provide a predictable, flexible, and procedurally fair legal order, the Bourbons understood the role that law plays in sustaining authority. Like their Hapsburg predecessors, they clearly associated notions of good 
government and the maintenance of political order with proper administration of justice. ${ }^{89}$ In fact, beginning in the 1750 s and continuing for the next four decades, Bourbon authorities on both sides of the Atlantic implemented a series of measures to improve the quality of justice, especially in procedural matters, measures that upheld and reinforced traditional Iberian juridical principles, such as arbitrio judicial..$^{90}$ The Bourbons most certainly sought public order in an era characterized by change and anxiety, yet, when we explore the innermost workings of criminal judicial institutions in Mexico City, it becomes clear that they did not seek order at any price. ${ }^{91}$

Department of History

Columbia, SC 29208

\section{ENDNOTES}

The author would like to thank Roberto Beristáin Rocha, Jaime del Arenal Fenochio, Linda Arnold, Charles Cutter, and Kathryn Edwards for their assistance in identifying and locating materials used in this paper. He also is grateful to Elaine Lacy, Jill Frank, Ann Kingsolver, Lawrence Glickman, Sonya Lipsett-Rivera, and the JSH anonymous reviewers for their comments and suggestions on earlier versions of this essay.

1. Archivo General de la Nación, Mexico (hereafter AGN), Criminal, vol. 625, exp. 7, fols. 140-144. Espinosa became an escribano shortly after migrating to Mexico City with his wife and infant daughter from his native city of Oaxaca, a medium-sized community in southern Mexico.

2. Donna Merwick examines the life of a Dutch scribe in seventeenth-century New York to explore a wide range of local and trans-Atlantic issues. Her reading of contemporary commentaries and other juridical publications "suggest that any understanding of legal practice at the time ... is incomplete without a recognition of the place of the notary." Death of a Notary: Conquest and Change in Colonial New York (Ithaca, 1999), 187.

3. Studies emphasizing the coercive and abusive nature of the criminal justice system in Bourbon Mexico City include Gabriel Haslip-Viera, Crime and Punishment in Late Colonial Mexico City, 1692-1810 (Albuquerque, 1999); José Arturo Yáñez Romero, Policía mexicana (Mexico City, 1999); Juan Pedro Viqueira Albán, Propriety and Permissiveness in Bourbon Mexico (Wilmington, 1999); and Colin M. MacLachlan, Criminal Justice in Eighteenth Century Mexico: A Study of the Tribunal of the Acordada (Berkeley, 1974). For more balanced understandings of criminal justice in the viceregal capital, see José Sánchez-Arcilla Bernal, "La Administración de Justicia inferior en la Ciudad de México a finales de la época colonial. I. La punición de la embriaguez en los Libros de Reos (1794-1798)," Cuadernos de Historia del Derecho 7 (2000): 309-453 and Teresa Lozano Armendares, La criminalidad en la ciudad de México, 1800-1821 (Mexico City, 1987). For overviews of the eighteenth and nineteenth critiques of colonial Mexican legal practices, see Robert Buffington, Criminal and Citizen in Modern Mexico (Lincoln, 2000), 9-37 and 111-118 and Jaime del Arenal Fenochio, "Instituciones judiciales de la Nueva España," Revista de Investigaciones Jurídicas 22 (1998): 9-41.

4. For a sample of monographs published in English since 1990, see Helen Nader, Liberty in Absolutist Spain: The Habsburg Sale of Towns, 1516-1700 (Baltimore, 1990); Nicolas Henshall, The Myth of Absolutism: Change and Continuity in Early Modern European Monarchy (London, 1992); James B. Collins, The State in Early Modern France (Cambridge, 1995); Richard Bonney, The Limits of Absolutism in ancien régime France (Variorum, 1995); Ruth MacKay, The Limits of Royal Authority: Resistance and Obedience 
in Seventeenth-Century Castile (New York, 1999). Moreover, one of the principal conclusions reached in the sweeping seven-volume series that recently examined the process of European state formation from the thirteenth to the eighteenth centuries was that "in practice the level of centralization, bureaucratization, and absolutism remained far below that assumed by earlier historians." Wim Blockmans and Jean-Philippe Genet, general eds. quoted in Wolfgang Reinhart, ed. Power Elites and State Building (New York, 1996), vii.

5. Mexican and Spanish scholars who are critical of the ways in which historians traditionally have represented Ibero-American legal systems contend that the only way to truly know how colonial law was perceived and operated is to study how judicial institutions functioned. By focusing on process, they claim, historians can uncover the routine practices of the government as a means of assessing the often harsh government and upper-class rhetoric of the late colonial era. Arenal Fenochio, "Instituciones judiciales de la Nueva España," 12 and Sánchez-Arcilla, "La Administración de Justicia inferior en la Ciudad de México," 309-311 and 450-451.

6. My approach is inspired by methodologies and theoretical frameworks which assert that perceptions and opinions about the state and acceptance of its authority are to be found, in part, in the way in which government institutions operate as well as in peoples' daily experiences in their encounters with agents or representatives of the state. The social psychological literature that focuses on the subject of procedural justice furthers our understanding of the multi-faceted nature of legitimacy by emphasizing the role that legal processes, rather than legal outcomes, play in the development of attitudes toward the law and the state. Based on research in the United States and in disparate European and Asian countries, leading scholars in this field posit that culturally expected standards of proper judicial process exist in all societies and that peoples' evaluations of their legal experiences are based largely on adherence to these standards and on the types of interaction with judicial officials. Even if people express some distrust of legal institutions, they nonetheless are committed to the legal ideal of having a culturally appropriate judicial hearing. Resulting judgements about the law and judicial institutions depend not simply on the final decision of the court, but also on whether people believe they were treated fairly by the judge and other judicial officials. Moreover, this social psychological literature demonstrates that compliance with procedural judicial norms enhances commitment and loyalty to the institutions of the state. Legitimacy, then, depends in large part on the process by which court decisions have been made. An excellent synthesis of this research is in Allan E. Lind and Tom R. Tyler, The Social Psychology of Procedural Justice (New York, 1988).

The works of legal scholars who stress the importance of daily encounters with the law in the formation of state power and popular politico-legal consciousness nicely complement the social psychological literature. For them, state power can be located in the everyday and intimate relationships that take place between the agents of the government, such as judicial officials, and people from across the social spectrum. Such close encounters inform us about how legal institutions and the state are experienced and therefore understood. Austin Sarat and Thomas R. Kearns, eds., The Law in Everyday Life (Ann Arbor, 1993).

7. Silvia Marina Arrom, Containing the Poor: The Mexico City Poor House, 1774-1871 (Durham, 2000), 6-7.

8. The "ordinary" or principal municipal criminal justice system in Mexico City consisted of both viceregal and city-level judicial officials. In an effort to rationalize this system, Viceroy Martín de Mayorga in 1783 divided the city into eight major administrative districts or cuarteles mayores, which were subdivided into thirty-two minor districts or cuarteles menores. High-ranking local and Iberian-born Spaniards served as the jueces mayores or chief judges of the eight district tribunals. These district magistrates consisted of the five ministers of the Sala del Crimen (alcaldes del crimen), the two locally-elected magistrates or alcaldes ordinarios, and the provincial royal official or corregidor. The newlycreated thirty-two alcaldes de barrio exercised judicial and administrative responsibilities 
in the minor districts. This system handled the majority of the criminal offenses in Mexico City, although there were other criminal jurisdictions in the capital in the late eighteenth and early nineteenth centuries, including, among others, the Tribunal del Alumbrado and the Juzgado de la Acordada. In addition to sources cited in note 3, see Michael C. Scardaville, "(Hapsburg) Law and (Bourbon) Order: State Authority, Popular Unrest, and the Criminal Justice System in Bourbon Mexico City," in Carlos Aguirre and Robert Buffington, eds., Reconstructing Criminality in Latin America, (Wilmington, 2000), 1-17; Woodrow Borah, Justice by Insurance: The General Indian Court of Colonial Mexico and the Legal Aides of the Half-Real (Berkeley, 1983).

9. Michael C. Scardaville, "Trabajadores, grupo domistico y supervivencia durante el el periodo colonial tardmo en la Ciudad de México, o 'La familia pequeqa no vive major,'” in La Poblacisn de la Ciudad de México en 1790: Estructura social, alimentacisn y vivienda, in Manuel Miqo Grijalva, ed. (Mexico City, 2003), 209-258; Eric Van Young, The Other Rebellion: Popular Violence, Ideology, and the Mexican Struggle for Independence, 1810-1821 (Stanford, 2001), 69-75; Arrom, Containing the Poor, 6-7, 11-39.

10. Sources that present an overview of the royal legislation on escribanos in colonial Mexico include Bernardo Pérez Fernández del Castillo, Historia de la escribanía en la Nueva España y el notariado en México. $2^{\text {nd }}$ ed. (Mexico City, 1988); Ivonne Mijares Ramírez, Escribanos y escrituras públicas en el siglo XVI: el caso de la ciudad de México (Mexico City, 1997), 13-71; Francisco de Icaza Dufour, "De los escribanos públicos en Nueva España," in El notariado en México a partir de su codificación (Florence, Italy, 1984), 40-77; José Sánchez-Arcilla Bernal, Las Ordenanzas de las Audiencias de Indias (1511-1821) (Madrid, 1992), 77-101, 117-140, 147-188, 311-388; Juan N. Rodríguez de San Miguel, Pandectas hispano-megicanas. 3 vols. (Mexico City, 1991; $2^{\text {nd }}$ ed.: Librería de J.F. Rosa, 1852), 3: nos. $4111,4601,4615,5131,5132,5138,5143,5144$.

11. The section of the Siete Partidas which lists royal officials in order of importance underscores the value of the scribes from the king's perspective. The notarios del Rey and the escribanos del Rey came after the capellán (royal chaplain) and the consejeros (counselors), but before the jueces del Rey (royal judges) and other judicial officers, such as the alguacil (constable), alférez (municipal standard bearer), and alcaldes (local magistrates). Partida 2, título IX, leyes 3-8, 18. For an overview of the legislation on scribes from the late thirteenth century through the reign of Ferdinand and Isabel, see, Mijares Ramírez, Escribanos y escrituras públicas en el siglo XVI, 36-43 and Icaza Dufour, "De los escribanos públicos en Nueva España," 40-52.

12. The judge's order to commence judicial proceedings against the accused, the auto cabeza del proceso, typically authorized the scribe to conduct necessary investigations "until uncovering the truth of the incident." Since magistrates also performed timeconsuming administrative duties in addition to their extensive judicial responsibilities, they generally were not present during the recording of testimonies and other court activities. As expressed in numerous royal laws dating to the late Middle Ages, many of which were ultimately codified in the seventeenth-century Recopilación de leyes de los reynos de las Indias, the purpose of the judicial investigation was to document the "cuerpo del delito" or corpus delicti as part of the pursuit to "know the truth." For instance, see Rodríguez de San Miguel, Pandectas Hispano-Megicanas, 3: no. 4606.

13. In the Romano-canonical civil law tradition of the European continent and the Iberian world, the judge often initiates and always supervises the criminal proceedings, thereby enhancing the importance of his court officials in the course of the investigation and other judicial activities. The magistrate in the so-called "adversarial" or lawyerdominated Anglo-American legal system typically plays a more passive role. The trial is the centerpiece in the common law legal tradition, while the judicial investigation represents the focal point of judicial activity in civil law jurisdictions. John Henry Merryman, The Civil Law Tradition: An Introduction to the Legal Systems of Western Europe and Latin 
America, $2^{\text {nd }}$ ed. (Stanford, 1985), 124-132; Alfonso García Gallo, Manual de historia del derecho español, $10^{\text {th }}$ edition. 2 vols. (Madrid, 1984); E.N. Van Kleffens, Hispanic Law until the End of the Middle Ages (Edinburgh, 1968); María Paz Alonso Romero, El proceso penal en Castilla (siglos XIII-XVIII) (Salamanca, 1982), 159-315; María del Refugio González, Historia del decrecho mexicano (Mexico City, 1997); James A. Brundage, Medieval Canon Law (London, 1995), 92-96; Herbert Jacob, "Courts and Politics in the United States," in Herbert Jacob, Erhard Blankenburg, Herbert M. Kritzer, Doris Marie Provine, and Joseph Sanders, eds., Courts, Law, and Politics in Comparative Perspective (New Haven, 1996), 16-80; Doris Marie Provine, "Courts in the Political Process in France," in Ibid., $177-248$.

14. Spanish colonial law followed fundamental precepts of continental civil law. Central to procedural norms, which were adapted from ecclesiastical courts of the twelfth and thirteenth centuries and refined by Castilian jurists over the next several hundred years, was the legal requirement to substantiate the charges in the course of the investigation. Francisco Tomás y Valiente, El derecho penal de la monarquía absoluta (siglos XVI-XVIIXVIII). $2^{\text {nd }}$ ed. (Madrid, 1992); Francisco Tomás y Valiente, Manual de historia de derecho español. $4^{\text {th }}$ ed. (Madrid, 1983); Brundage, Medieval Canon Law, 60-61, 92-96, 111-112, 120-153, 188-189.

15. Rodríguez de San Miguel, Pandectas Hispano-Megicanas, 2: no. 4606. The king's sentiments were echoed in Mexico City. Francisco Arcipreste, one of the city's lay magistrates, noted in 1809 that the legality of the judicial process and the lawfulness of the judges' sentences depended on the presence and performance of the escribanos. AGN, Civil, vol. 2156, exp. 4, no folios. In a letter to the viceroy written in the same year, the governing board of the Real Colegio de Escribanos described the scribes as judicial officials "in whom rests the authority of the Lord Judges and the depositaries of the public faith." Ibid., exp. 3, no folios.

The Iberian legal tradition, as well as the predilection of Bourbon policymakers, tended to privilege scribes rather than lawyers in the criminal justice system. Professional lawyers (letrados) did not play a major role in the administration of criminal justice, largely since standard judicial procedure called for their participation only towards the later, or plenario, phase part of a criminal case. Nonetheless, they were active in civil litigation and were employed in a variety of royal agencies in Mexico City, especially in the Audiencia, the highest-ranking court in New Spain.

16. For a list of all the royal escribanos in New Spain in 1794, see AGN, Bandos, vol. 17 , exp. 66, f. 302 . In spite of the relative scarcity of formally trained and titled scribes outside of Mexico City, judicial actions in all criminal and civil cases nevertheless required legal validation. Recognizing the shortage of these key officers in the provincial courts, the Spanish crown authorized in 1588 two methods of properly witnessing and recording judicial actions. Local royal officials could either appoint an interim scribe, someone with the requisite literacy skills, or solicit two honorable members of the community to act as witnesses to any judicial proceeding. Woodrow Borah, "Los auxiliares del gobernador provincial," in Woodrow Borah, ed., El gobierno provincial en la Nueva España, 1570-1787 (Mexico City, 1985), 50-51 and 60-61; María del Refugio González and Teresa Lozano. "La administración de justicia," in Ibid., 96-105; Jorge Corvalán Meléndez and Vicente Castillo Fernández, Derecho Procesal Indiano (Santiago, 1951), 81, 196, 208.

17. AGN, Bandos, vol. 17, exp. 3, fols. 28-36; AGN, Escribanos, vol. 22, exps. 7 and 8; Charles R. Cutter, The Legal Culture of Northern New Spain, 1800-1810 (Albuquerque, 1995), 77; Mijares Ramírez, Escribanos y escrituras públicas en el siglo XVI, 42, 80; Rodríguez de San Miguel, Pandectas Hispano-Megicanas, 3: no. 4049; Icaza Dufour, "De los escribanos públicos en Nueva España," 55-57; Fernández del Castillo, Historia de la escribanía, 49.

18. In the organizational scheme of the viceregal agencies, escribanos were assigned to the legal offices (asesorias) since they were expected to prepare, not merely copy documents on various administrative and legal issues. Linda Arnold, Bureaucracy and Bureaucrats in 
Mexico City, 1742-1835 (Tucson, 1988), 25-26. See Mijares Ramírez for a discussion of the scribe's professional judicial stature in the early colonial period. Escribanos y escrituras públicas en el siglo XVI, 45.

19. In a larger sense, the scarcity of scribes was part of a broader pattern since all levels in the colonial bureaucracy experienced a shortage of personnel in the late eighteenth and early nineteenth centuries. Institutions at the viceregal level were understaffed in the late colonial period, even though Bourbon administrative activism increased governmental responsibilities. Arnold, Bureaucracy and Bureaucrats in Mexico City, 24-47.

20. A fully staffed criminal justice system Mexico City, as stipulated in the Ordinance which authorized its expansion, required scribes for each of the eight judges (jueces mayores) and the thirty-two alcaldes de barrio. Yet of the seventy-five escribanos reales who practiced in the capital in the mid-1790s, almost three-quarters already held a salaried position in one of the viceregal agencies or in municipal government. In principle, the royal scribes who were most readily available to be assigned to a judicial official were those who did not hold any remunerative institutional affiliation, but there were only twentyone of these escribanos reales, about one-half of the requisite number. AGN, Bandos, vol. 17, exp. 66, fol. 302 .

21. See Article 7 in the "Ordenanzas de la división de México en Quarteles, creación de Alcaldes de Barrio, y reglas de su gobierno, con una mapa de la ciudad," AGN, Bandos, vol. 12 , fols. 101-124. The viceroy appointed deputy scribes from a list submitted by the eight magistrates of the newly-created courts. Escribanos habilitados were invested with authority to participate solely in criminal proceedings. Because of the complexities of civil law, as well as the monopoly that certain royal scribes held over this branch of the law, the 1782 Ordinance explicitly excluded deputy scribes from participating in civil litigation and notarial transactions.

22. Assignment to more than one cuartel menor was so common that the printed appointment form used the plural form ("menores") for the minor districts. See, for instance, the documents submitted by Mariano Espinosa in his 1795 petition, AGN, Criminal, vol. 625 , exp. 7. It appears, however, that the viceroy commissioned first-time deputy scribes to assist in only one of the minor districts. They would be assigned to additional districts after acquiring several years of experience.

23. The most common patterns in multiple district appointment, as seen in the career paths of Juan Vargas and Ignacio Ramírez de Arellano, was to assist two to four of the alcaldes de barrio or, as in the case of Julian Roldan, work an institutional scribe in the Sala del Crimen and serve at least one of the local police officials. AGN, Civil, vol. 2156, exps. 3 and 4. For additional examples of viceregal appointments of escribanos habilitados, see AGN, Ayuntamientos, vol. 211, exp. 9 and AGN, Escribanos, vol. 21, exp. 57.

24. As Chandler and Burkholder note, the Spanish crown successfully reduced creole participation in high-ranking Audiencia positions by the end the eighteenth century, yet as this examination of scribes in Mexico City illustrates, locally-born Spaniards comprised the majority of these low-level court officials. The expanded criminal justice system and the importance of the scribes in this system gave creoles an opportunity to actively participate and shape local and viceregal judicial institutions. I would not go as far as to suggest that the expanded judiciary enabled creoles to resist peninsular takeover of royal government in late colonial period, but I believe it would be safe to say that it gave a heretofore unrecognized voice to some moderately educated, middle-class creoles at time of peninsular appropriation of government institutions. D.S. Chandler and Mark A. Burkholder, From Impotence to Authority: The Spanish Crown and the American Audiencias, 1687-1808 (Columbia, 1977). I wish to thank Linda Arnold for providing me with personal information on the scribes from her unpublished collection of biographical data of late colonial royal bureaucrats who served in Mexico City. 
25. There was a long tradition in the Iberian world of providing practical manuals and guides for scribes and lay magistrates. These legal texts and formularies, which spelled out judicial procedure and discussed matters of criminal and civil law in a simple manner, were available in cities and larger provincial communities in New Spain in the eighteenth century. Examples of such materials include Formulario de causas criminales (Mexico City, 1751), Libro de los principales rudimentos tocante a todos juicios, criminal, civil y executivo. (Mexico City, 1764), and the two volume work by Joseph Juan y Colón, Instrucción de Escribanos en Orden a lo Judicial (Madrid, 1787), the second volume of which focused on "juridical instructions" to scribes, lawyers, and magistrates of the lower courts. Susana García León, ed., "Un formulario de causas criminales de la Nueva España," Anuario Mexicano de Historia del Derecho 9 (1997): 83-148; Charles R. Cutter, ed., Libro de los principales rudimentos (Mexico City, 1994).

26. Espinosa, for instance, ultimately worked as a scribe in Mexico City for over three decades (1788-1820). Among the many escribanos who served local judicial officials for extended periods of time are Rafael Cartami (1787-1828), Mariano Urueña (18031820), and Rafael Castro (1797-1814). AGN, Criminal, vol. 625, exp. 7; AGN, Civil, vol. 2156, exps. 3 and 4; Linda Arnold, Directorio de burócratas en la ciudad de México, 1761-1832 (Mexico City, 1980), 39, 63, 89, 277-278.

27. The magistrate offered these positive assessments as part of an 1809 investigation into the alleged abuses in the appointment of escribanos habilitados. The inquiry commenced when the senior local magistrate, Francisco Arcipreste, contended that an unspecified number of the deputy scribes did not have what he deemed to be proper titles of appointment. He expressed concern that some of these escribanos might have exercised their duties even though they were never issued formal printed titles of their appointment, that sometimes more than one had been appointed to serve in the same district, and finally that some also may have continued to serve after their term had expired. Arcipreste persuaded Viceroy Francisco Javier de Lizana y Beaumont that it was time to investigate and remedy these alleged abuses as well as explore the possibility of using only formally trained escribanos reales in all the minor districts of the capital. The Viceroy ordered the jueces mayores to review the status, appointments, and, additionally, the personal and professional conduct of the deputy scribes. The resulting investigations uncovered only one improper title of appointment, and they did not expose any inappropriate or unsatisfactory conduct of the escribanos habilitados. All but one of the magistrates, the senior lay city magistrate who lodged the complaint, praised the quality of their work in spite of their many duties and overall workload. Although Arcipreste presented no proof of unsatisfactory professional conduct on the part of any deputy scribe in his jurisdiction, which he surely would have done if it had been existed, he nonetheless conjectured that scribes trained in the Real Colegio de Escribanos would have performed better. It is important to note that the sole dissenting judge was not a letrado while those magistrates who uniformly and enthusiastically commended their deputy scribes, the alcaldes del crimen, were professionally-trained jurists.

In an effort to protect and promote the prerogatives of their institution and its personnel, the board members of the Real Colegio de Escribanos nonetheless asked Viceroy Lizana to annul the appointments of the deputy scribes, most of whom, they asserted, were of questionable quality and character, and appoint instead escribanos reales who had been educated at the Colegio and examined by the Audiencia. However, the governing board, like alcalde Arcipreste, was not able to specify abuses on the part of any specific escribano habilitado, either presently or since they were initially used in the early 1780 s. The board members resorted to generalities and character assassination of the deputy scribes, claiming at one point that half of them, as a result of their "vices and bad conduct," "had prostituted themselves." The general tenor of the board's comments reflected frustration that viceregal and local officials did not adhere to the standard procedure for the appointment of royal scribes and relied instead on a clause in the 1782 Ordinance that allowed the viceroy to by-pass the Colegio and the Audiencia and deputized individuals who had been recommended by the city's magistrates. AGN, Civil, vol. 2156, exps. 3 and 4 . 
28. The three municipal-level magistrates, the two alcaldes ordinarios and the corregidor, did not possess any formal legal education and therefore, as required by law, were assisted by a legal advisor (asesor letrado), a lawyer or jurist who reviewed and approved all court sentences and other major judicial orders issued by the lay judges. See, for instance, Archivo Judicial del Tribunal Superior de Justicia del Distrito Federal, Mexico City (hereafter AJT), Penal, vol. 6, exp. 47; Borah, Justice by Insurance, 96-97. The unremunerated position of alcalde de barrio was filled with private citizens, mainly petty proprietors, the magistrates nominated and the viceroy appointed because of their local standing and reputation, not because of any professional expertise. In accordance with Spanish political philosophy and legal texts, appointment or election to judicial posts depended more on character, integrity, and judgement than on command of juridical knowledge. See Partida 3, título IV, ley 3 of the Siete Partidas; Ricardo Zorraquín Becú, La función de justicia en el derecho indiano (Buenos Aires, 1948), 31-33. See note 33 for comments about citing materials in the AJT.

29. For instance, the alcaldes de barrios, who, as jueces originarios, had the limited authority to instigate criminal proceedings before turning the case over to their juez mayor for final sentencing, did not enjoy the services of an asesor letrado and therefore had to rely extensively on their scribe's knowledge of the penal process. For an example, see AJT, Penal, vol. 9, exp. 5. Through their advice to the lay magistrates and the alcaldes de barrio on points of substantive and procedural law, the escribanos made colonial law more understandable and made certain that the judicial officials adhered to procedural norms and processes.

30. The alcaldes de barrio and the alcaldes ordinarios typically served for a two-year period. Periodically, moreover, the senior alcalde ordinario jointly held the position of corregidor, which meant that he was the juez mayor of the tribunals of the sixth and seventh major districts as well as the magistrate of the very active Tribunal del Alumbrado, the court of the street lighting guards. AGN, Ayuntamientos, vol. 177, exp. 9. Also see Lozano Armendares, La criminalidad en la ciudad de México, 19.

31. The viceroy appointed the escribanos for a period of two years, although they generally were re-appointed if they had performed satisfactorily. See AGN, Criminal, vol. 625, exp. 5.

32. The legal expertise of escribanos who worked for one of the five alcaldes del crimen, all of whom were highly-educated jurists, was obviously not as critical as it was for the three lay magistrates and the alcaldes de barrio. For the advisory role that scribes performed in early colonial Mexico City and elsewhere in Spanish colonial America, see Mijares Ramírez, Escribanos y escrituras públicas en el siglo XVI, 46; Jorge Luján Muñoz, Los escribanos en las Indias Occidentales, y en particular en el Reino de Guatemala (Guatemala, 1977), 71-72; Tamar Herzog, Mediación, archivos y ejercicio: Los escribanos de Quito (siglo XVII) (Frankfurt am Main, 1996), 29-32.

33. In descending order of occurrence, the most frequent criminal charges involved drink-related offenses, common-law marriage/adultery, theft, sexual misconduct, assault, and illegal gambling. More than nine of ten arrests involved members of the working poor and involved a cross-section of this group in terms of ethnicity, although Indians $(38 \%)$, males $(74 \%)$, and artisans $(50 \%)$ were over-represented in the court cases. We should not disregard the fact that women and lower-class creoles respectively comprised $26 \%$ and $41 \%$ of the arrests. Michael C. Scardaville, "Crime and the Urban Poor: Mexico City in the Late Colonial Period" (Ph.D. diss. Gainesville, 1977), 34-47.

Of the criminal cases analyzed, 7,067 came from ten extant arrest and court inventories (Libros de reos) formerly located in two municipal judicial archives in Mexico City, the Archivo Judicial del Tribunal Superior de Justicia del Distrito Federal and the Archivo General del Juzgado, Mexico City (hereafter AGJ). Since I first consulted the documents in the AGJ, however, the historical records were misplaced during a renovation of the building. The pre-1950 documents of the AJT were recently moved to the Mexican 
national archives, the Archivo General de la Nación, but are still being catalogued. Since these materials have not yet been completely indexed, I continue to cite them in accordance with their former provenance. The remaining 296 cases analyzed for this essay consisted of full-length, formal criminal cases (causas criminales) located in the collection of the Archivo Judicial del Tribunal Superior and in the Ramo Criminal in the Archivo General de la Nación. For an excellent discussion of the Libros de reos, including comments on the missing police and court inventories of the AGJ, see Sánchez-Arcilla, "La Administración de Justicia inferior en la Ciudad de México," 316-332.

Many historians and nineteenth-century critics of Spanish colonial justice have based much of their censure of the criminal justice system in Mexico City, particularly its alleged abusive, arbitrary, and corrupt nature, on the commentaries of the late eighteenth-century observer, Hipólito Villarroel, not on a comprehensive and systematic examination of the case files. Moreover, a careful reading of Villaroel's criticism of the judicial system illustrates that his charges are levied primarily at the operation of the civil, not criminal, court procedure and that his denunciation of the escribanos has little basis in the case file evidence. México por dentro y fuera bajo el gobierno de los vireyes, o sea enfermedades políticas que padece la capital de esta Nueva España en casi todo los cuerpos de que se compone y remedios que se le deben aplicar para su curación si se quiere que sea útil al rey y al público (Mexico City, $1831), 36-40,46-50$. For a discussion of how his accusations shaped later perceptions of criminal justice in the Bourbon colonial Mexico City, see Buffington, Criminal and Citizen in Modern Mexico, 15-17, 21, 25. Woodrow Borah's brief biographical study of Villarroel suggests that his indictment of the colonial legal system should be used with considerable caution. "Alguna luz sobre el autor de las Enfermedades políticas," Estudios de Historia Novohispana 8 (1985): 51-79.

34. I estimated the average caseload by examining the daily arrest patterns in the Libros de reos, particularly those maintained by the escribanos of the alcalde ordinarios and alcaldes de barrio nos. 21, 22 and 23. AGJ, Libros de reos, alcalde ordinario mas antiguo, 1800; Libros de reos, alcalde de barrio número 21, 1800; Libros de reos, alcalde ordinario menos antiguo, 1807; AJT, Libros de reos, alcalde ordinario mas antiguo, 1795; Libros de reos, alcalde ordinario mas antiguo, 1796; Libros de reos, alcalde ordinario mas antiguo, 1798; Libros de reos, alcaldes de barrio numeros 22 y 23, 1798. The 1810 report of cases dispatched by the magistrates and scribes of the Sala del Crimen reflects similar patterns. AGN, Real Acuerdo, vol. 20, exp. 150, f. 28.

35. Our petitioner Mariano Espinosa, for instance, worked with one of the jueces mayores as well as the four of the alcaldes de barrio in his jurisdiction. AGN, Civil, vol. 2156, exps. 3 and 4 .

36. Juicios ordinarios, also referred to as procesos ordinarios, constitute the more formal and extensive criminal cases (causas criminales) the scribe ultimately archived upon their completion. The Libros de reos comprise an inventory of the juicios sumarios or, as they are sometimes called, juicios or procesos verbales. Based on Roman and canon law precedents, medieval and subsequent Spanish law authorized juicios sumarios in order to minimize expenses and expedite the judicial process, particularly for those minor offenses in which the accused confessed or the evidence was more than sufficient for the judge to issue a sentence. See the sections in the mid-eighteenth formularies on "De proceso criminal abreviado" in García León, "Un formulario de causas criminales," 146 and "Proceso Criminal abrebiado (sic)" in Cutter, Libro de los principales rudimentos, 57; Francisco Tomás y Valiente, Gobierno e instituciones en la España del Antiguo Régimen (Madrid, 1982), 240-244; Montero Aroca, La herencia procesal española, 65-79; Rodríguez de San Miguel, Pandectas Hispano-Megicanas, 1: no. 1789; Brundage, Medieval Canon Law, 139-140 and 144-147. For the extensive use of summary or abridged hearings in the Juzgado General de Indios and other Spanish American colonies, see, respectively, Borah, Justice by Insurance, 13-15 and Corvalán and Castillo, Derecho Procesal Indiano, 193-194. Handling criminal cases in a summary fashion was also a common practice in English and American courts in the seventeenth, eighteenth and early nineteenth centuries. Peter King, Crime, Justice, and Discretion in England, 1740-1820 (Oxford, 2000); Clive Emsley, Crime and Society 
in England, 1750-1900, $2^{\text {nd }}$ ed. (London, 1996), 12; Bradley Chapin, Criminal Justice in Colonial America, 1606-1660 (Athens, 1983), 28-30.

37. Contrary to what nineteenth-century penal critics and most historians of the colonial Mexican judicial system have claimed, summary, that is, abridged, trials did not mean arbitrary justice and an abuse of legal guarantees. The magistrates followed standard criminal procedures in the juicios sumarios, and they did not presume the guilt of the accused. As repeatedly seen in the case files, the preliminary testimony gathered by the scribe generally determined the culpability of the defendants as well as the seriousness of the offense. The general pattern was that the judge released the accused in the absence of corroborating evidence, or issued his sentence if there was proof of a minor transgression. If the scribe's initial judicial inquiry indicated a more serious offense, the judge then formed a sumaria, which initiated a more formal criminal investigation called a juicio ordinario.

38. For excellent discussions of the more formal criminal judicial procedure used in juicios ordinarios, see Cutter, The Legal Culture of Northern New Spain, 105-146, Lozano Armendares, La criminalidad en la ciudad de México, 165-167, and Montero Aroca, La herencia procesal española, 29-63.

39. I do not wish to categorize the Ibero-American judicial process as being inherently rigid and inflexible. While standard and formulaic to a certain degree, it also exhibited a legally authorized flexibility. Law codes and royal legislation afforded magistrates the right to abridge the criminal investigation if the accused confessed and, as I later discuss, modify the sentence to fit the circumstances of the case. See Cutter, The Legal Culture of Northern New Spain, 130-148; Corvalán and Castillo, Derecho Procesal Indiano, 193-194 and 213-214.

40. The general patterns I will describe reflect the work routine of all the escribanos, although some of the specific quotidian responsibilities depended on the officials they served and on the type of viceregal appointment, i.e. royal or habilitado. For instance, the five salaried scribes who assisted the magistrates of the Sala del Crimen, such as the receptores and relatores, performed institutional duties for the high criminal court in addition to the ones described in the essay. Moreover, it is not possible in the scope of this article to discuss all the possible judicial activities undertaken by the different types of escribanos or the many dimensions of the criminal judicial proceedings, such as the nature of court sentences. These and other issues will be addressed in my forthcoming monograph on the administration of criminal justice in Mexico City from the mid-eighteenth century to the 1830 s.

41. Prisoners tried in the courts of the five jueces mayores of the Sala del Crimen were confined in the royal jail. Prisoners in the city jail fell under the jurisdiction of the two alcaldes ordinarios and the corregidor. Escribanos de la cárcel, one at each jail, maintained the Libro de entradas. AGN, Bandos, vol. 3, exp. 28; AGN, Criminal, vol. 116, exp. 2; AJT, Penal, vol. 8, exp. 62.

42. See AGN, Criminal, vol. 715, exp. 11, f. 246 for information concerning the sala de declaraciones. Concerning the expeditious way in which testimony should be taken, Charles III issued the following instruction to corregidores in 1788: "that within twentyfour hours after imprisonment, any prisoner, without exception, shall give his statement since it is not just to deprive a free man of his liberty without promptly knowing the reason why it was taken away from him." Rodríguez de San Miguel, Pandectas HispanoMegicanas, 3: no. 5138. Case evidence shows that the escribanos routinely recorded the initial statement within one day after the arrest.

43. This daily routine was slightly altered every Thursday and Saturday morning when, in preparation for the weekly visits to the royal and city jails, all scribes personally delivered status reports of the active juicios ordinarios to the oidores, the highest-ranking magistrates 
of the Audiencia, or to the alcaldes ordinarios. Eusebio Ventura Beleña, Recopilación sumaria de todos los autos acordados de la Real Audiencia y Sala del Crimen de esta Nueva España. 2 vols. (Mexico City, 1991), 2: no. 9, art. 9, 44-45.

44. In the interest of expediting justice, the law required scribes to notify the prisoner of the sentence no later than one day after the judge pronounced it. Rodríguez de San Miguel, Pandectas Hispano-Megicanas, 1: no. 1997. According to the case evidence, this was routinely done on same day. For the role of escribanos in the sentencing process, see Ibid. no. 1701.

45. For a listing of these records, see AJT, Penal, vol. 13, exps. 1-4.

46. See, AJT, Penal, vol. 4, exp. 9 and vol. 10, exp. 5.

47. The majority of arrests in the eight district tribunals occurred after someone, typically a working-class person, filed a charge with an alcalde de barrio or a magistrate. In 1798, for instance, this meant that Indians, castas, and poor creoles filed over 3,000 criminal charges in the lower courts of Mexico City. Arrests based on complaints were higher in certain offenses, especially family-related problems, vagrancy, theft, and commonlaw marriage/adultery. Scardaville, "Crime and the Urban Poor," 10-11 and 35. The expansion in the number of courts and judicial officials in the early 1780s as well as the low cost of summary justice facilitated access to and use of the criminal justice system by the urban poor, regardless of their economic situation and ethnicity. The reduction and even elimination of court fees for indigents gave people from all social groups access to the criminal judicial system. Civil litigation involved significantly greater costs than did criminal cases. See notes 62 and 67 for additional comments on criminal and civil court expenses.

48. AGN, Criminal, vol. 625 , exp. 5 involves a case of a man brandishing a sword at the scribe and other judicial officials who were attempting to arrest him.

49. Clearly, this portrait of a typical day represents an ideal scenario. It does not include those days when the escribano was ill or distracted by family or other matters. Nor should we assume that all scribes were always and equally diligent in fulfilling their responsibilities. However, the case file evidence involving dozens of escribanos over almost a thirty-year period consistently reflects a high degree of professional commitment and performance.

50. AGN, Criminal, vol. 73 , exp. 5, fs. 303-303v. The oidores or alcaldes ordinarios reviewed the status of each major criminal file (juicio ordinario) in the presence of the prisoner and the scribe who handled the case to determine whether it should continue or, because of delays, be expedited or terminated.

51. See, for instance, AJT, Penal, vol. 3, exp. 9 and exp. 51; vol. 8, exp. 49; Archivo Histórico del Distrito Federal, Mexico City (hereafter AHDF), Policía en General, vol. 3628, exp. 72.

52. See, AJT, Penal, vol. 8, exp. 32. In addition to his routine duties, Mariano Espinosa served as the scribe in the 326 cases generated during the levas de vagos conducted in 1797 and 1798. AGN, Criminal, vol. 625, exp. 7.

53. Pre-constitutional Ibero-american governments, which were shaped largely by medieval political principles, were not characterized by a separation of executive, legislative, and judicial powers. As representatives of the king, who embodied all four dimensions of governance, royal officials in varying degrees exercised multiple responsibilities. Judges and police officials performed at a minimum judicial (justicia) and administrative (gobierno or policía) duties. Some officials, like the corregidores, also discharged fiscal (hacienda) and 
military (guerra) obligations. For a succinct discussion of the relationship between justicia and other governmental functions, see Zorraquín Becú, La función de justicia, 17-22 and 26-30.

54. For an overview of these activities relating to Policía, see AHDF, Alumbrado, vol. 345, exp. 8; AHDF, Policía en General, vols. 3628 and 3629.

55. The royal scribes who assisted the lay magistrates also were known as escribanos de numero or escribanos públicos and exercised a monopoly on all notarial duties in the city. In addition to their work in civil suits, these escribanos públicos prepared, maintained, and archived the specific legal instruments and the Libros de protocolos that comprise today's notary archives in Mexico City. Rodríguez de San Miguel, Pandectas HispanoMegicanas, 2: no. 3610; Fernández del Castillo, Historia de la escribania, 55-56; Mijares Ramírez, Escribanos y escrituras públicas en el siglo XVI, 45-47; 56-57; Icaza Dufour, "De los escribanos públicos en Nueva España," 53, 88-89, 94. See note 21 concerning the exclusion of deputy scribes from notarial duties and civil litigation.

56. Spanish law specified limits on the length of time required for certain judicial procedures. One such law in the 1462 Ordenamiento de Alcalá, for instance, decreed that magistrates must issue the final sentence no longer than twenty days after the investigation had been completed. Rodríguez de San Miguel, Pandectas Hispano-Megicanas, 3: no. 4108. The case evidence shows that this was routinely done, often long before the three-week limit.

57. The typical escribano was not simply trying to get through the day as quickly as possible. After reading many criminal cases, my sense is that the testimonies of witnesses and the accused were relatively unstructured affairs in which their length and detail varied in accordance with what person needed or wanted to express. Moreover, the scribe's charge in the judge's auto cabeza del proceso gave him latitude to decide whether additional actions, such as conducting a careo or locating additional witnesses, were necessary to resolve any discrepancies in the evidence. Seen in this light, the principal investigative charge of the escribanos was to provide, if possible, a file of congruent testimony and other evidence to the judge so that he could make an informed deliberation. Again, my impression, based on the case evidence, is that the scribes did not compromise the judicial actions required of them.

58. Rodríguez de San Miguel, Pandectas Hispano-Megicanas, 3: no. 5139. This order should not be read as evidence of widespread judicial abuse in Mexico City. Typically the origin of such royal decrees is found in complaints that had been submitted by colonial officials or subjects from any part of the empire, but the characteristic response of the Spanish monarchy was to issue injunctions that were applicable throughout the colonies. In this sense, this particular royal decree provided the king an opportunity to reaffirm standard and expected judicial practices.

59. In spite of the legally-sanctioned social inequalities of the era which customarily shaped the sentences of the court, the case evidence also shows that the courts systematically extended procedural safeguards to all of the accused, regardless of their class, ethnicity, gender, and age.

60. Many petitions submitted to the magistrates end with the phrase: "es Justicia," an assertion suggesting that members of popular groups expected that the legal system would be procedurally fair and that justice would be served. Although such court documents were drawn up with the assistance of a scribe to ensure that they followed certain juridical forms, they are nonetheless one reflection of the extent to which working class people from different backgrounds possessed legal knowledge and expressed legal expectations. As the literature on procedural fairness illustrates, notions of justice are based just as much on receiving a fair hearing than on obtaining a desired court ruling. See note 6 for an elaboration of this point. 
While historians typically have explained the application of due process as a royal favor or as an act of royal benevolence, recent research points to the existence of a concept of rights, including the notion of due process, that has roots in twelfth-century canon law developments in Western Europe. These studies demonstrate the emergence of a juridical-political consensus that all members of society possessed inalienable, individual God-given rights, not merely communal or corporate rights. A theory of individual rights, which encompassed the principle of a defendant's legal rights, had become widely accepted in Western jurisprudence by the end of the thirteenth century and subsequently was incorporated into Spain's influential legal code, the Siete Partidas. The development of a natural rights discourse that preceded the rise of early capitalism and the Enlightenment offers additional insight into why the courts of Bourbon Mexico City, even in the absence of specific constitutional requirements, strictly adhered to procedural norms for individuals from even the lowest, and the most feared, social classes. According to medieval jurists and restated time and again in more secularized forms in succeeding centuries, the king and his agents could not withhold such rights since they were bound by a higher, natural law. Brian Tierney, The Idea of Natural Rights: Studies on Natural Rights, Natural Law and Church Law, 1150-1625 (Atlanta, 1997); Annabel S. Brett, Liberty, Right, and Nature: Individual Rights in Later Scholastic Thought (Cambridge, 1997); Kenneth Pennington, The Prince and the Law, 1200-1600: Sovereignty and Rights in the Western Legal Tradition (Berkeley, 1993); Brundage, Medieval Canon Law, 81-97; Jorge M. Ayala, "Antecedentes medievales de los derechos humanos," Veritas: Revista de Filosofia 44 (1999): 853-864; Mackay, The Limits of Royal Authority, 173-177.

61. For a discussion of how legal protections contribute to regime legitimization, see Lind and Tyler, The Social Psychology of Procedural Justice; Jacob, "Introduction," in Courts, Law, and Politics in Comparative Perspective, 13-14.

62. Other court practices reflective of the late colonial legal culture also contributed to notions of fairness and effectiveness, such as speed of justice, cost, and final court sentences. The judges waived certain kinds of judicial expenses for indigents and, as previously noted, handled the vast majority of cases expeditiously. The magistrates' sentences in juicios sumarios generally were temperate, with the courts acquitting or placing on probation nearly one-quarter of all of the accused. Fines, which accounted for 29 percent of the sentences in summary cases, were the most frequently used judicial penalty. Of the thousands of cases analyzed, there were no incidences of capital punishment, and corporal punishment was rarely used by the first decade of the nineteenth century. For extended discussions of the generally moderate court sentences in both the juicios ordinarios and juicios sumarios, see Scardaville, "Crime and the Urban Poor," 276-308; Lozano Armendares, La criminalidad en la ciudad de México, 169-180; and Sánchez-Arcilla, "La Administración de Justicia inferior en la Ciudad de México," 357 and 447-448.

63. For the authorized escribano fee structure (arancel) in criminal cases, see AGN, Bandos, vol. 3 exp. 27.

64. Ibero-American law authorized this abbreviation of the formal judicial process. As specified in the Siete Partidas, the plenario was necessary only if the sumaria or probatory phase did not conclusively demonstrate the culpability of the accused or, in complex cases, fully document the nature of the criminal offense. Montero Aroca, La herencia procesal española, 39; Corvalán and Castillo, Derecho Procesal Indiano, 213-214. Moreover, case file evidence demonstrates that the municipal judges customarily terminated the process upon the completion of the investigative phase if charges against the accused were not substantiated. In Mexico City, few juicio ordinarios went the full procedural distance.

65. AGN, Bandos, vol. 3, exp. 27.

66. Recopilación de leyes de los reynos de las Indias, Libro II, título 23, leyes, 48 and 52. For the purpose of fee waivers, Spanish law defined indigence as not possessing any property, a condition many working-class people were able to satisfy. Rodríguez de San 
Miguel, Pandectas Hispano-Megicanas, 1: no. 2009. Also see, Ibid., 3: no. 4189; Lozano Armendares, La criminalidad en la ciudad de México, 168-169.

67. As discussed in note 33, Villarroel's late eighteenth-century criticism of extortion generally related to civil, not criminal, cases. Also see Rodriguez de San Miguel's comment that scribes in post-independence Mexico City, in spite of sixteenth-century legislation to the contrary, tended to postpone taking action in civil suits involving poor people in favor of those filed by wealthier litigants who could more easily afford the necessary judicial fees and unsanctioned gratuities. Pandectas Hispano-Megicanas, I, no. 1685. Richard L. Kagan's study of the civil law process in Hapsburg Spain presents an excellent discussion of the widespread corruption and excessive delays that characterized the handling of lawsuits in the Castilian judicial system. Lawsuits and Litigants in Castile, 1500-1700 (Chapel Hill, 1981), 37-51.

68. In one 1804 case, the Sala del Crimen removed scribe Francisco Santaella from office after the court substantiated an accusation that he took a gratificación (unauthorized fee) in an case involving common-law marriage. The Ministers of the high criminal court rejected his petition to be reinstated. In this particular instance, the couple involved possessed the financial means to offer a substantial bribe. AGN, Criminal, vol. 625, exp. 5 . The alcaldes del crimen removed scribes from office on other occasions after investigations corroborated the charges of "abuses" or "excesses." While some escribanos did indeed betray their positions of trust, we also must recognize that the Sala del Crimen, in spite of the shortage of escribanos, took decisive action once charges were filed and verified. Protecting anyone who accused a judicial official of misconduct was the anonymity he or she maintained during the probatory or sumaria phase of the investigation. See, AGN, Ayuntamientos, vol. 222, exp. 2 and AGN, Civil, vol. 2156, exp. 4, no folios.

69. According to the Rector of the Real Colegio de Escribanos, the deputy scribes often performed fee-based notarial transactions, lucrative judicial behavior that was contrary to royal legislation and the 1782 enabling ordinance that limited their responsibilities to criminal jurisdiction. AGN, Civil, vol. 2156, exp. 3, no folios.

70. See, for instance, AGN, Criminal, vol. 89, exp. 1

71. For a sampling of such examples, see AGN, Criminal vol. 89, exp. 9; vol. 715, exp. 2; AJT, Penal, vol. 3, exp. 65; vol. 6, exp. 29.

72. One dimension of the sumaria illustrates this point. As stipulated by law, the accused did not have a right to review the other testimonies gathered in the course of the scribe's preliminary investigation, although the defendant would be informed of the reason for his or her imprisonment. Knowledge of these statements and their contents would occur if the case is advanced to the next phase of the process, the plenario, when a series of judicial proofs would be offered to all parties. It should be kept in mind that the secrecy of the probatory phase, as is the case for grand jury investigations in common law traditions, was not an illegal abuse on the part of the authorities. Such judicial behavior was standard practice since the Siete Partidas codified penal procedure and was inherent in the nature of continental civil law judicial administration. Corvalán and Castillo, Derecho Procesal Indiano, 212; Tomás y Valiente, Gobierno e instituciones en la España, 229. Michel Foucault discusses the ways in which the secretive nature of the preliminary investigation in French criminal procedure of the ancien régime represents another "technology of power" the state used to control and subjugate people charged with a crime. Discipline and Punish: The Birth of the Prison (New York, 1995), 35-42.

73. Testifying under oath, especially in the confines of the sala de declaraciones in the jail, certainly represented an inequality in power relations between the escribano and the accused, but unlike the taking of statements in eighteenth-century French jails, prisoners in Mexico City were not made to sit or kneel on uncomfortable chairs or stools (sellettes), 
and the municipal courts in the viceregal capital, unlike those of pre-Revolutionary Paris, did not employ torture as a means of extracting confessions or statements. Richard Mowery Andrews, Law, Magistracy and Crime in Old Regime Paris, 1735-1789. Vol. 1: The Criminal Justice System (Cambridge, 1994), 429, 441-466; Antoinette Wills, Crime and Punishment in Revolutionary Paris (Westport, Conn., 1981), 6-9. Andrews does note, however, that the incidence of investigative torture was declining in the late eighteenth century, 454 . The application of torture was permissible under Spanish law until prohibited by the Constitution of 1812 , and therefore would have been dutifully recorded in the criminal files as were all judicial actions, but I did not find one instance of its use in over 7,000 cases. For supporting evidence, see Lozano Armendares, La criminalidad en la ciudad de México, 185 and Sánchez-Arcilla, "La Administración de Justicia inferior en la Ciudad de México," 371-453.

74. For the historical and juridical basis of arbitrio judicial, see Tomás y Valiente, El derecho penal de la monarquía absoluta, 295-317, 320, 331-352, 375-380; Corvalán and Castillo, Derecho Procesal Indiano, 156, 177-184, 193-231; Brundage, Medieval Canon Law, 151-156. The fundamental principles of this judicial doctrine are expressed in Partida VII of the Siete Partidas. For a discussion of the practice of arbitrio judicial in Mexico City and provincial New Spain, see Sánchez-Arcilla, "La Administración de Justicia inferior en la Ciudad de México," 371-453; Cutter, The Legal Culture of Northern New Spain, 35-43; González and Lozano, "La administración de justicia," 101-102; Mario A. Téllez González, La justicia criminal en el Valle de Toluca, 1800-1829 (Zinacantepec, 2001), 177-186.

75. For a discussion of these criticisms of arbitrio judicial, see Buffington, Criminal and Citizen in Modern Mexico, 12-21 and 111-119, Téllez González, La justicia criminal en el Valle de Toluca, 177-178, and Fabio López-Lázaro, "No Deceit Safe in Its Hiding Place: The Criminal Trail in Eighteenth-Century Spain," Law and History Review 20 (2002), 449478. Sánchez-Arcilla notes that the eminent Spanish legal historian Francisco Tomás y Valiente also erroneously conflated arbitrio judicial with magisterial arbitrariness. "La Administración de Justicia inferior en la Ciudad de México," 363-367 and 450-451. Tomás y Valiente, El derecho penal de la monarquía absoluta, 376-389.

76. The perfunctory effort to eliminate the "excesses" associated with the pulque (pulquerias) and hard liquor taverns (vinaterias) is a typical example of the way in which Mexico City's judicial officials modified laws and penalties. Generally, the local magistrates and police officials passively enforced government sanctions on drinking taverns, and for those working class people who were arrested for such violations, the judges often reduced the penalty stipulated in the laws. Michael C. Scardaville, "Alcohol Abuse and Tavern Reform in Late Colonial Mexico City," Hispanic American Historical Review 60 (1980): 643-671.

77. The periodic conscriptions of alleged vagrants (levas de vagos) during the late $1790 \mathrm{~s}$ were an exception, however. Because of the need to quickly replenish vacant military positions during wartime, one of the ministers of the Sala del Crimen, as mandated by the Ordenanzas de Levas, streamlined normal criminal procedures. Although evidence collected by the escribano was still required to substantiate the charge of vagrancy, there were occasions when the royal prosecuting attorney (fiscal), as a form of plea-bargaining, encouraged the accused to confess in order to reduce his sentence. See, for example, AGN, Criminal, vol. 715, exp. 16.

78. For British historians, the ceremonial nature of eighteenth-century English criminal courts, as public symbols of sovereign authority, conveys the power of the state. According to E.P. Thompson, for instance, the "hegemony of the eighteenth-century gentry and aristocracy was expressed, above all, not in military force, not in the mystifications of a priesthood or of the press, not even in economic coercion, but in the rituals of the study of the Justices of the Peace, in the quarter-sessions, in the pomp of the Assizes and in the 
theatre of Tyburn." Whigs and Hunters: The Origin of the Black Act (New York, 1976), 262. For similar comments about the "majesty of law," see Douglas Hay, "Property, Authority and the Criminal Law", in Douglas Hay, Peter Linebaugh. John G. Rule, E.P. Thompson, and Cal Winslow, eds., Albion's Fatal Tree: Crime and Society in Eighteenth Century England (New York, 1975), 120. North American scholars also have underscored the connection between the ceremonial nature of American courts and maintenance of social order. See Jacob, "Introduction," in Courts, Law, and Politics in Comparative Perspective, 12.

79. Historians are generally mistaken about the public nature of the criminal judicial process in Bourbon Mexico. Contrary to what has been asserted by scholars of crime in eighteenth-century New Spain, public trials and courthouses were not part of the colonial Mexican legal system. For instance, see Haslip-Viera, Crime and Punishment in Late Colonial Mexico City, 81.

80. The only opportunity for a magistrate to encounter prisoners under his jurisdiction was during his weekly inspections of the jail, but, as previously noted, the majority of the accused were sentenced and released in less than a week.

81. Civil cases also were handled bureaucratically through the submission of written documents by the litigants. Corvalán and Castillo, Derecho Procesal Indiano, 83.

82. By "assured," I do not mean that respect for state authority was unchanging and guaranteed. As becomes patently evident in Mexico during the post-1810 independence era and following decades, public authority is always dependent on current developments and consequently is in a constant state of interpretation and negotiation.

83. The literature on procedural justice has demonstrated a strong positive connection in Western and non-western societies between the nature of the judicial process and opinions about and acceptance of political and legal institutions. Lind and Tyler conclude that "judgements of process fairness were consistently the major factor involved in generalizations from personal experience to system-level views." Although they use terms like procedural justice and procedural fairness interchangeably, they "do not mean to imply that cultures that lack concepts easily translatable as 'fairness' lack procedural effect. We believe that whether violation of an entitlement is labeled 'unfair' or 'inappropriate' or 'impolite,' the psychological consequences are much the same." The Social Psychology of Procedural Justice, 3, 76-81, 129-145, 203-220.

84. He earned a 200-peso salary for his position as relator (official who prepares legal briefs), a post that required scribe certification even though Espinosa was still classified as an escribano habilitado. He paid a price for the financial stability the position afforded. In addition to his extensive institutional responsibilities, he also served as scribe to one of the jueces mayores and to all four alcaldes de barrio in one of the major administrative districts. The magistrate, Manuel Mariano de Blaya, who was a jurist by training, gave Espinosa high marks for his professional conduct and knowledge. Espinosa continued to work as a deputy scribe in different judicial capacities in the Sala del Crimen until 1820. AGN, Criminal, vol. 625, exp. 5; AGN, Civil, vol. 2156, exp. 3; Amold, Directorio de burócratas en la ciudad de México, 39.

85. Other tribunals in Mexico City, such as the Alumbrado, the Inquisition, the Indios, and the Acordada, also behaved in a similar fashion. For case examples, see AJT, Libros de reos, corregidor, 1794, 1796, 1798; AGN, Criminal, vol. 84, exp. 11; vol. 641, exps. 6 and 7. Also see Borah, Justice by Insurance, 232-233; William F. Connell, "Transformation of a Criminal Court in Mexico City: An Inquiry into the Real Tribunal de la Acordada, 1775-1812." M.A. thesis (Columbia: University of South Carolina, 1997). As noted previously, this moderate use of judicial power in the late colonial period also is evident in the generally temperate sentences handed down by all courts. 
86. We should be sensitive to the fact that popular rejection of specific laws and government initiatives, which some of the urban poor viewed as inimical to their beliefs and customs, did not invalidate a general acceptance of legal institutions.

87. My research on law enforcement suggests a more reactive urban constabulary than has often been portrayed, a conclusion based in large part on detailed examination of daily police practices. I do not find considerable evidence in the use of force and coercion in the every day behavior of the alcaldes de barrio, guardafaroleros (street lighting guards), and other judicial agents in Mexico City.

88. I again stress the need to historicize our understanding of the legal system in particular and the colonial state in general. In attempting to examine the criminal justice system, scholars must be wary of broad generalizations in terms of time and place as a result of differing institutional, economic, and, demographic conditions. My study applies specifically to late colonial Mexico City, but I ultimately hope to raise issues and processes that can be explored in different contexts.

With this said, I should note as a preliminary point of comparison that courts in some parts of rural New Spain, including those in the frontier provinces of New Mexico and Texas, and in the Spanish colonies of Chile, Río de la Plata, and Ecuador, display a remarkable adherence to procedural norms in spite of the absence of trained jurists and scribes. Perhaps these procedural similarities in vastly different and far-flung parts of the Spanish American empire suggest a fairly broad understanding and acceptance of Iberian legal norms throughout the colonies. This tentative conclusion clearly has to be substantiated by more extensive examination of local court records in many parts of New Spain and other regions of the Americas. González and Lozano, "La administración de justicia," 88-105; Cutter, The Legal Culture of Northern New Spain; Corvalán and Castillo, Derecho Procesal Indiano, 42, 406-417; Zorraquín Becú, La función de justicia, 24; Tamar Herzog, La administración como un fenómino social: la justicia penal de la ciudad de Quito (1650-1750) (Madrid, 1995), especially chapter 8.

Moreover, in a forthcoming article on this enduring colonial legal culture in the early national period, I note that the introduction of modern constitutional forms of government in the early nineteenth century did not alter basic colonial juridical principles. "Los procesos judiciales y la autoridad del Estado: reflexiones en torno a la administración de la justicia criminal y la legitimidad en la ciudad de México, desde fines de la Colonia hasta principios del México independiente," in Brian Connaughton, ed., Poder y Legitimidad en México, Siglo XIX. Instituciones y Cultura Política (Mexico City, forthcoming).

89. Tomás y Valiente and Alonso Romero discuss the continuity of medieval and Hapsburg legal principles under the Bourbons. El derecho penal de la monarquía absoluta, 93-112, 380, 407-408 and El proceso penal en Castilla, 317-335.

90. One of the best examples of the numerous late eighteenth-century legal reform initiatives was the successful effort to eliminate the arbitrary procedural practices of the Tribunal of the Acordada, a judicial institution created earlier in the century to deal swiftly and, if necessary, severely with rural crime and banditry. MacLachlan, Criminal Justice in Eighteenth Century Mexico, 71-74 and 84-87; Connell, "Transformation of a Criminal Court in Mexico City." For the procedures the Acordada magistrates and escribanos were required to follow after 1776, see, AGN, Acordada, vol. 9, fs. 180-195.

91. This understanding of what I call the "judicial state", and especially the operation of the criminal justice system, is very much at odds with historians of crime in colonial Mexico City who envision law as being largely coercive. They focus more on how the state sustains domination by force, or threat to use force, than on how authority can be created though cultural meanings. Legal anthropologist Sally Engle Merry, in her critique of this one-dimensional view of law, explores the multi-faceted manner in which law can establish support for authority. As she notes, "law exerts both coercive power and subtle cultural domination." Getting Justice and Getting Even: Legal Consciousness among Working-class Americans (Chicago, 1990), 8-11. 